San Jose State University

From the SelectedWorks of Ericka B. Adams

2019

"I've Risen Up From the Ashes That I Created": Record Clearance and Gendered Narratives of Self-Reinvention and Reintegration

Elsa Y Chen, Santa Clara University

Ericka B. Adams, San Jose State University 
"I've Risen Up from the Ashes that I Created":

Record Clearance and Gendered Narratives of Self-Reinvention and Reintegration

\author{
Elsa Y. Chen* \\ Professor \\ Department of Political Science \\ Santa Clara University \\ 500 El Camino Real, Santa Clara, CA 95033 \\ (408) 551-7055 \\ echen@scu.edu \\ Ericka B. Adams \\ Assistant Professor \\ Department Justice Studies \\ San Jose State University \\ One Washington Square, San Jose, CA 95192 \\ (408) 924-3339 \\ ericka.adams@sjsu.edu
}

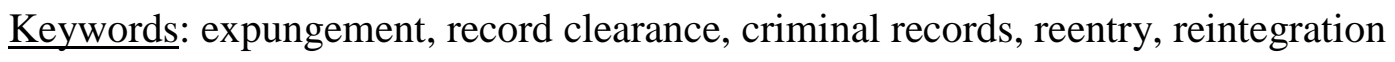

*Please direct all correspondence to this author. 


\title{
"I've Risen Up from the Ashes that I Created": Record Clearance and Gendered Narratives of Self-Reinvention and Reintegration ${ }^{1}$
}

\begin{abstract}
Record clearance allows some individuals to redesignate or remove certain minor convictions from their criminal records. This interview-based study finds that both men and women seek opportunities for personal gain through record clearance, but women are more motivated by moral and religious influences and concern about reputation. Women are also more likely than men to acknowledge personal flaws, and to desire to replace criminal identities with law-abiding identities. As women redefine their identities, caregiving is especially important as a personal obligation and professional aspiration. Record clearance is particularly compatible with women's motivations, willingness to change, and personal and professional goals.
\end{abstract}

\section{Introduction}

About 25 percent of all adults in the U.S. have had state or federal criminal convictions (Jacobs, 2015). A criminal record can significantly impede efforts to obtain housing, jobs, educational advancement, and certain welfare benefits. The inability to access these resources, in turn, can damage family relations and make successful desistance from crime especially challenging (Adams, Chen, and Chapman, 2017). The proliferation of criminal records is one consequence of the era of mass incarceration, particularly the War on Drugs, which brought rapid growth in the number of female prisoners and parolees (Bui and Morash, 2010; Bureau of Justice Statistics, 2015; Petersilia, 2003). Men have always outnumbered women in prison and parolee populations, but from 1980 to 2014, the population of incarcerated women grew over seven-fold, from 26,378 in 1980 to 215,332 in 2014, outpacing the growth in the male prison population by over 50 percent (The Sentencing Project, 2015). There are important differences between female and male correctional populations, and by extension between women and men

\footnotetext{
${ }^{1}$ The authors with to thank Rosella Chapman, Caitlin Massey, and Emma Lloyd for their valuable research assistance.
} 
reentering society with criminal records. Compared to men, women are much more likely to have been convicted of drug offenses and less likely to have committed violent offenses, and they are more likely to have been addicted to drugs or alcohol (Mears \& Cochran, 2014). Women’s incarceration histories also differ from men's, with women on average having been convicted of less serious offenses and incarcerated for shorter periods (Lalonde \& Cho, 2008). Additionally, women are more likely to have custody of their children prior to incarceration, less likely to receive support from romantic partners while incarcerated, and more likely to face the stigma associated with being a "bad mother" and difficulty reunifying with their children upon release (Dodge \& Pogredin, 2001). These differences between men and women warrant a closer examination of the strategies for successful reintegration after conviction among the sexes.

Research on reintegration of formerly convicted persons (FCPs) has focused primarily on males, rather than including both men and women. Likewise, reentry programs tend to be designed in ways that are responsive to the behaviors and needs of men, rather than considering gender differences (Bloom, Owen, \& Covington, 2004; Herrschaft, Veysey, Tubman-Carbone, \& Christian, 2009). Policies based on a more thorough and nuanced understanding of the factors that influence women's efforts to reintegrate into society could have important implications for FCPs, their families and communities, the labor force and economy, and public safety.

The current study combines rigorous quantitative and qualitative analyses of data from participants in a program designed to expunge offenses from their criminal records. Unlike the samples that form the basis of most prior studies, our sample includes roughly equal numbers of male and female participants. We find significant differences between men's and women's narratives of their experiences as they seek to overcome obstacles associated with their criminal backgrounds. Furthermore, this study focuses on a policy approach, record clearance, that has 
received scant empirical attention. Record clearance is important because it targets persons with lower-level offenses, who make up the vast majority of ex-convicts, and whose quality of life, productivity, and ability to contribute to their families and communities could be greatly improved with modest investments in appropriate programs intended to facilitate their efforts to move beyond their criminal histories.

\section{Identity change and reintegration after incarceration}

The literature on prisoner rehabilitation, reentry, and reintegration includes several widely-employed theoretical frameworks that contribute to an understanding of how record clearance can facilitate identity change, desistance, and successful reintegration. Laub and Sampson (2003), whose approach is grounded in social control theory, emphasize the importance of certain aspects of the social and physical environment of FCPs, including informal social control (e.g. the forms of control associated with significant others and children) and routine activities (such as those associated with marriage and employment), while focusing less on the importance of individuals’ agency and choice. Under this framework, individuals change their behavior as a response to changes to their circumstances, but changes in self-perception and identity are not required for desistance from crime to occur (Paternoster, Bachman, Bushway, Kerrison, \& O’Connell, 2015). Record clearance can help FCPs access stable housing, gainful employment, and other positive changes to their circumstances.

In contrast, Paternoster and colleagues’ identity theory of desistance (Paternoster et al., 2015; Paternoster \& Bushway, 2009) focuses primarily on individual-level decision-making. Their work emphasizes the importance of identity change - a process that involves several steps, from a FCP's dissatisfaction with his or her current/working identity, to awareness of a "feared self” that they wish to avoid, to adoption of a prosocial "possible self” - as a necessary precursor 
to desistance (Paternoster \& Bushway, 2009; Rocque, Posick, \& Paternoster, 2016). Individual human agency is central to this theory (Paternoster et al., 2015). Maruna also emphasizes individuals’ conscious decisions, focusing on their efforts to "make good" and to construct personal narratives that fit with their self-conceptions as non-criminal, productive members of society, a process referred to as “rebiographing” (Maruna, 2001). In contrast to FCPs who recognize flaws in their identities and try to adopt new, different identities, those engaged in “rebiographing” reconstruct their personal histories, focusing on elements of their past that “deemphasize the centrality of crime in their life history” and suggest that they were good, “normal” people with positive qualities “all along” (Maruna, 2001, p. 89-90).

Giordano, Cernkovich, and Rudolph (2002) combine individual and social/environmental factors in a symbolic-interactionist framework of cognitive transformation. Here FCPs become ready to change, realize the changes that they desire are incompatible with continued deviance, become exposed to "hooks for change" in their environment, begin to envision a "replacement self,” and no longer view deviant activity as positive, viable, or personally apropos (Giordano et al., 2002). Often, the ability to initiate and sustain cognitive transformation is associated with shifts in a person's coping abilities and his or her emotional states (Giordano, et al., 2007). The cognitive transformation framework emphasizes not only interior, psychological changes, but also the interaction between the FCPs and the opportunities and constraints in their environment that influence options and decisions during the process of change (Giordano et al., 2002; Giordano et al., 2007).

These frameworks - particularly those that combine personal and social factors - are useful for our analysis of individuals’ expectations and experiences of record clearance. Individual-level transformation may be of limited value without institutional and structural 
support to facilitate true reintegration and success (Owen, 2009). Despite changes in their selfperception, individual decision-making processes, marital status, and other characteristics, FCPs may remain hampered by the stigma of a criminal record. Thus, it is through the dual lenses of individual decision-making and societal roles, expectations, opportunities, and limitations that we examine women's expectations and experiences of criminal record expungement in the present study and compare them with those of men. Women and men are subject to different social expectations and roles. These influence the decisions that they make and the identities that they can adopt as they pursue law-abiding lives after expungement. In this study, we find that the support structures, opportunities, and constraints that facilitate or limit women's and men's ability to access options for change also differ.

To thoroughly understand distinctions in the experiences of men and women with criminal records in their attempts to reintegrate pre- and post-record clearance, it is essential to situate their experiences within a gendered society. The social structure of gender produces profound psychological, behavioral, and social expectations and consequences for men and women (West \& Zimmerman, 1987). Gender, although not always at the forefront of interactions (Miller, 2002), infuses various aspects of life. For instance, the division of labor generally positions more difficult, better paid managerial jobs as men's work, and caretaking jobs, which require fewer qualifications, as women's work (Connell, 1987). Gender influences the perceptions of persons who commit crimes and their experiences before and after punishment. Steffensmeier \& Allan (1996, p. 470) consider crime a male-dominated arena into which women are pushed through "victimization, role entrapment, economic marginality, and survival needs." Taboos against female criminality stem from the characterization of nurturing roles, female beauty, and sexual virtue as endemic to femininity (Steffensmeier \& Allan, 1996). It is also 
essential to note that gender is not static; it intersects with factors such as race, class, sexuality, and generation in structuring behaviors (Miller, 2002).

Women's and men’s different social expectations and roles influence the decisions that they make and the identities that they can adopt after accruing one or more criminal convictions. Living with an unlawful romantic partner increases the probability of crime commission for persons with a criminal record; however, this effect exerts greater influence over women (Benda, 2005). In addition to external factors, Dodge and Pogrebin (2001) note that women encounter a significant level of internalized shame due to their criminal conviction. Interestingly, number of children is inversely associated with recidivism for women (Benda, 2005), and women with children were more likely to succeed on parole than women with no children (Huebner, DeJong, \& Cobbina, 2010). Along these lines, friendships and family-of-origin relationships provide a buffer against recidivism for women (Benda, 2005). For men, in contrast, it is years of education and job satisfaction that are inversely related to recidivism (Benda, 2005). These findings can be explained by women's tendency to prioritize social relationships and interpersonal responsibility. The current study adds to the growing body of empirical research that examines both men's and women's incarceration, rehabilitation, and reentry experiences and the factors that influence those experiences (see, e.g. Bates, 2004; Herrschaft et al., 2009; Uggen \& Kruttschnitt, 1998). In doing so, we go beyond existing models that were developed and tested using samples comprised entirely or mostly of male research subjects (Aresti, Eatough, \& Brooks-Gordon, 2010; Laub \& Sampson, 2003) and studies that shed light on women’s experiences, but focus exclusively on female FCPs (e.g. Bui \& Morash, 2010; Cobbina, 2010; Cobbina \& Bender, 2012; Leverentz, 2014; O’Brien, 2001a, 2001b; Opsal, 2011, 2015; Richie, 2001). Our findings highlight certain differences between men and women in their expectations and experiences with 
the process of criminal record clearance as well as their reintegration experiences after record clearance. We also focus on topics that are emphasized in women's narratives but received less attention from men. As such, we make theoretical, empirical, and practical contributions to our collective knowledge about the reintegration of FCPs.

\section{Data and Methods}

\section{The Record Clearance Project}

The Record Clearance Project (RCP), created in 2008 by Margaret (Peggy) Stevenson, J.D., involves undergraduates (under the supervision of an attorney) in efforts to assist clients seeking to clear their criminal record(s) in Santa Clara County, California. ${ }^{2}$ To be eligible for RCP services, individuals must have been convicted of a misdemeanor or felony in Santa Clara County for which they served a sentence of up to one year in jail or a lesser sentence; must have discharged probation where applicable; and must not owe restitution. Convictions received outside Santa Clara County are ineligible for expungement through this program. The types of convictions cleared through the RCP include, but are not limited to, assault, assault with a deadly weapon, resisting arrest, driving under the influence, possession of drug paraphernalia, some forms of sexual assault, and domestic violence. While misdemeanors are eligible for expungement through the RCP, felony convictions, for which the client served less than one year in jail, must first be reduced to misdemeanors and then expunged.

Potential clients learn about the Record Clearance Project through community education presentations, information tables at events, and agency presentations by RCP students and staff; referrals from the Probation Department, Department of Corrections, and Public Defender's

\footnotetext{
${ }^{2}$ The program currently serves only Santa Clara County, but similar programs could be established in other jurisdictions, as options for expungement exist in many states (Jacobs, 2015).
} 
Office; and word of mouth from former clients or others. Once interested individuals contact the Record Clearance Project, formal entry into the program begins with a speed screening. Here the potential client meets an RCP student who reads his or her list of criminal convictions and determines whether the client is eligible. Clients accepted into the program are then paired with a team of students who prepare the petition to request record clearance. Included in this petition are the client's list(s) of criminal convictions, a brief history of the client, legal and discretionary reasons for granting expungement, and letters of support from members of the community who can attest to the client's post-conviction accomplishments. Once the petition is submitted, the client is given a court date when he or she goes before a judge for an expungement hearing. At the hearing, lawyers representing the District Attorney and Department of Probation have an opportunity to respond to the petition and recommend that it be granted or denied. The Defense Counsel presents the case and the client has an opportunity to explain why s/he is a good candidate for expungement. The RCP has a 99 percent success rate for expungement and a 96 percent success rate for felony reductions[EC1] (M. Stevenson, personal communication, April 30, 2013).

It is important to note that a level of self-selection is present with RCP clients. They have made a conscious decision to try to clear their records, often with specific objectives in mind, such as gaining better jobs or improving relationships with family members. Individuals who proceed with record clearance have, in many cases, desisted from using drugs and are in the process of finding legal employment. Furthermore, the speed screening process and the process of preparing a petition filter out individuals who are unable to articulate a clear plan to maintain desistance from crime and drugs. Due to self-selection into the Record Clearance Project, our study does not comprise a random sample of FCPs; however, the sample is appropriate for the 
purposes of understanding better the motivations and experiences of those who initiate and undergo record clearance.

\section{Interview data}

The data analyzed for this study were drawn from semi-structured interviews with 40 individuals with criminal records. Half of the sample had completed the record clearance process, successfully expunging one or more of their criminal convictions, while the other 20 were interested in, but had not yet completed, record clearance. Interviewees were recruited using two strategies. First, for three years prior to data collection, the interviewer attended various RCP events including speed screenings, court hearings, community information sessions, and meetings with the RCP director and students. This enabled the interviewer (co-author Adams) to become familiar with the RCP and facilitated interviewee recruitment. Twenty-five respondents were recruited directly from RCP events. Second, after obtaining permission from clients, the RCP director provided the researchers with a list of clients—both people who obtained record clearance and those on the waitlist. The remaining fifteen respondents were recruited from calls to this list.

The interviews were performed in a private-public location (e.g. University office, private room at a public library) with each interview lasting approximately one hour. All research participants were over the age of 18, provided informed consent, and agreed to be audiorecorded. Particular to this project, respondents were informed that the research was independent of the RCP and had no bearing on past or future expungements or relationship with the RCP. Audio recordings allowed each interview to flow like a conversation while capturing the details of respondents' nuanced experiences. Respondents were compensated for their time and the 
inconvenience of traveling to the interview site with a \$20 Visa gift card. Each interview was transcribed, and two members of the research team independently coded each transcription.

The final interview guide consisted of 57 questions. Some of the interview questions analyzed for this article are: (1) Has your conviction(s) limited your life in any way (employment, professional licensing, student loans, government benefits/services, any other opportunity)? (2) Did your conviction(s) impact your relationship with your loved ones (e.g. children, parents, partners, other relatives, friends, etc.)? (3) Did your conviction(s) impact how you viewed yourself? (4) Since your last conviction, has your perception of yourself changed?

(5) What caused your perception of yourself to change? (6) What made you decide to participate in the record clearance process? (7) What has having your convictions cleared meant to your life? and (8) Did having your conviction(s) cleared change your relationship with your loved ones?

\section{Analysis}

Grounded theory methodology guided the data analysis, which commenced during the data collection phase with initial coding (Charmaz, 2006). Once interviews were transcribed, the authors analyzed participants' actions and their processes for record clearance. Transcribed interviews were read line by line to further develop inductive categories (Charmaz, 2011). Once a coding frame was agreed upon, each interview was coded by two researchers. If new codes emerged during the focused coding phase, previously-coded interviews were recoded. Thematic memos were then written to develop research participants’ meanings and actions and tease out any connections between them (Charmaz, 2011; Thomas, 2006). This process ensured that the story that emerged was derived from participants’ reality. 
Once the thematic memos were developed, a spreadsheet was created that summarized characteristics of each respondent. This included demographic and socioeconomic information (gender, race, age group, income level, parental status, relationship status, highest education completed, and type of employment), crime type, and which themes each person discussed. This enabled the authors to crosstabulate themes mentioned in the interviewees' narratives with demographic and socioeconomic traits to determine the extent to which certain aspects of the participants' narratives varied systematically with personal characteristics within our sample. ${ }^{3}$

\section{Findings}

Out of the 40 total interview respondents, 18 were women, including seven of the 20 respondents who had completed the RCP program and 11 of the 20 individuals who had registered for RCP but remained on the waiting list. There were no statistically significant differences between the male and female subsamples in their race/ethnicity, age, marital status, parental status, highest level of education completed, reported income levels, or type of employment. The whole sample included 13 African Americans (32.5\%), 12 whites (30\%), ten Latinos (25\%), three Asian Americans (7.5\%), and two Native Americans (5\%). ${ }^{4}$ Five percent of the sample were between the ages of 20 and 29, 32.5\% were $30-39$, 35\% were $40-49$, and $27.5 \%$ were 50-65 years old. Forty percent were married, 12.5\% were divorced, and the remaining

\footnotetext{
${ }^{3}$ Because of the small sample size and the fact that we could supplement patterns detected in the crosstabulations with substantive evidence from the qualitative analysis of interview data, we chose to use $\alpha=0.10$ as the cutoff for statistical significance.

${ }^{4}$ Individuals who self-identified as half-black were included coded as black, and those who identified as halfAmerican Indian were coded as Native American. The sample size was not large enough to separate the various iterations of multiracial identity out into distinct categories. Furthermore, this decision stems from an understanding of race as a fluid social construct that includes both self-identification and classifications assigned by others based on physical appearance and other factors, and that can change over time and from one context to another, particularly for multiracial individuals (Doyle and Kao, 2007). Saperstein and Penner (2010) find that both racial self-identification and external racial classification can be influenced by the experience of incarceration. Their analysis of longitudinal data finds that individuals are more likely to self-identify as "black" and less likely to identify as "white" after having been in prison, and they are also more likely to be classified by others as "black" if they have been previously incarcerated (Saperstein and Penner, 2010).
} 
47.5\% were single; $72.5 \%$ had children. When asked about their education, $12.5 \%$ reported not having finished high school, $17 \%$ had a GED, $7.5 \%$ were high school graduates, 32.5\% had some college, $17.5 \%$ were college graduates, and $10 \%$ had completed post-graduate degrees.

Unemployed persons made up 32.5\% of the sample; $10 \%$ worked in unskilled labor, including retail and foodservice; 25\% had jobs that involved skilled or licensed labor or caregiving, including security guards and bus or truck drivers; and 32.5\% had white collar/professional jobs, including case managers and self-employed businesspersons. Summary statistics can be found in Table 1.

[Table 1 about here]

The women in our sample were more likely to have drug or nonviolent convictions, and men in our sample had more violent convictions. Despite our nonrepresentative sample, this distribution is consistent with nationwide statistics about women with criminal records (Bloom et al., 2004; Herrschaft et al., 2009; Mauer, 2013; Wright, Van Voorhis, Salisbury, \& Bauman, 2012). Among women, five (27.8\%) reported that the most serious conviction for which they were seeking record clearance had been for a drug or DUI offense; for 11 women (61.1\%) it was a nonviolent crime that was not a drug or alcohol offense; and two women (11.1\%) had a violent conviction. Among men, the corresponding numbers were four (18.2\%) for drugs or DUI, six (27.3\%) for other nonviolent offenses, and 12 (54.5\%) for a violent crime, including weapons possession. The differences were significant at $\mathrm{p}=0.015\left(\chi^{2}=8.409,2\right.$ d.f. $)$.

The narratives of the women and men shared many common themes associated with the effects of their convictions, expectations from record clearance, and outcomes that had been experienced by those who had completed RCP. However, several themes appeared with greater prevalence in women's narratives than in men's narratives. We will focus primarily on notable 
gender differences that we uncovered, based on close reading and coding of interview transcripts and confirmed by statistical analysis of the coded data. Table 2 summarizes the proportion of female and male respondents who spoke about each of the themes discussed below.

[Table 2 about here]

Completion of the record clearance process can potentially lead to a number of tangible benefits, such as greater access to better-paying and more stable jobs, housing, and educational opportunities. However, going beyond the desire to gain access to material benefits, we found that women were more likely than men to emphasize three other important reasons for wanting to expunge their criminal records: the desire to become a better caregiver, moral or religious motivations, and concern about their reputation. These observations are consistent with the conclusions of Herrschaft, et al (2009), who found that among people with criminal records, women's narratives of transformation were much more likely than men's narratives to attribute positive changes to "relationship-related factors" - including personal connections with family members and friends, the desire to help others, and relationships with religious figures (Herrschaft et al., 2009).

\section{Motherhood and family caregiver roles}

Women have complicated attachments to their children (Michalsen, 2011) and thus there are inconsistent reports on the impact of children on recidivism. Curcio, Pattavina, and Fisher (2016) found that having children was significantly and negatively associated with desistance. However, they also found that after controlling for other factors, having children proved insignificant in relation to desistance (Curcio et al., 2016). Formerly incarcerated mothers encounter difficulties with mothering upon release; they may struggle to obtain housing, establish a livelihood, care for children with physical and mental health challenges, and become 
reacquainted with their children (Harm \& Phillips, 2001; Michalsen, 2011). Foster children who encounter maternal incarceration experience longer placement terms (Ehrensaft, Khashu, Ross, \& Wamsley, 2003) and if their mothers’ parental rights were terminated, reunification becomes almost impossible (Dodge \& Pogrebin, 2001; Michalsen, 2011). Though experiencing these challenges, Michalsen (2011) notes that formerly incarcerated mothers spoke at length of their love for and pride in their children, many placed the needs of their children above their own desires (e.g., reunifying with their children), and others noted that they desisted from crime because any future criminal activity would leave no one to care for their children.

Even though slightly more men than women had children and spouses, a much higher proportion of women in our sample (13, or $72.2 \%$ ) than men (seven, or 31.8\%) spoke about caregiving as a personal obligation, profession, or calling ( $p=0.011, \chi^{2}=6.465,1$ d.f.). The broad conceptualization of “caregiving” used here includes child care, elder care, and health care. It also includes providing assistance to others who are undergoing the process of desistance from drugs or crime.

Caring for children was a central theme among female respondents; several women talked about wanting to leave behind drugs and crime and pursue new opportunities for the sake of their own children. ${ }^{5}$ Melissa, for example, stopped using drugs primarily for her child's sake. ${ }^{6}$

I found out I was pregnant and I used three times after I found out I was pregnant in the very early stages of my pregnancy. And I told my husband I'm either going to have an abortion or I'm going to get clean but I will not bring a child into this world addicted to methamphetamines. I won't do it. ... And I got clean that day

\footnotetext{
${ }^{5}$ Throughout this paper, we frequently discuss respondents' desires to be drug-free and their efforts to desist from crime together. This is because many of the individuals in our sample spoke of drugs and crime at the same time. Seventy percent of our interviewees (72\% of the women and $68 \%$ of the men) acknowledged having been drug users, and an additional ten percent ( $6 \%$ of women and $14 \%$ of men) acknowledged alcohol abuse without drug use. For many respondents, their criminal activity was inextricably linked to their drug or alcohol problems, even if their convictions were not for drug-related offenses; as such, staying clean and sober was a key component of their plans to complete record clearance and to move forward with crime-free lives.

${ }^{6}$ To protect the confidentiality of study participants, all names in this paper are pseudonyms.
} 
and I never looked back. ... That was my choice. I was either going to die or I was going to live for my kids.

Cognizant of the impact that drugs could have on her unborn child, Melissa became drug-free to give her daughter a life free from avoidable health ailments. Likewise, after being addicted to crack for about 20 years, when Wanda got arrested, she wanted to "clean myself up and be a better parent to my kids.” Other mothers in our sample said that they became motivated to expunge their records so they could get a job and better care for their children. Women's care for their children is one of society's many gendered expectations. Women who violate the law have the added pressure of being viewed as social outcasts and inadequate parents (Dodge \& Pogrebin, 2001). For the women in our sample, attempting to become a responsible caregiver could be seen as their endeavor to achieve society's expectation of gendered responsibilities. Alternatively, a more skeptical interpretation might be that vocalization of a desire to care for others reflects women's efforts to articulate objectives that are consistent with society's narratives around women and caregiving, regardless of the degree to which they actually intend to pursue caregiving goals. Either way, one can see the influence of gendered expectations on formerly convicted women's narratives around caregiving.

When they spoke about caregiving in relation to their motivations for pursuing record clearance, men's articulation of providing care appeared to be centered on their own life experiences, as opposed to an emotional or ethical obligation to help others. The types of support men spoke about were more likely to fall into the realm of providing a system of material support as opposed to providing physical or emotional care. A few men did mention providing for their children and wanting their children to be proud of them. Carl, a 44-year-old Caucasian man with convictions for possession of drug paraphernalia and DUI, said, "I'm going to be successful one day and do something that my children are going to be proud of ... I want to be 
able to head my own house one day and put a roof over their head.” Here, Carl describes wanting to be a provider and a head of household, which are traditionally masculine roles. At times, even when male respondents worked with children, caregiving was not an aspect of their work that they emphasized. Adrian, a 33-year-old African American man with a misdemeanor counterfeit charge and a "wet reckless," currently works as "a family specialist for a wraparound program with kids” but did not characterize working with children as a personal or professional obligation. ${ }^{7}$ In fact, his caregiving role only came up incidentally when he spoke of his employment.

\section{Caregiving as a vocation}

Past research has found that the "ability to find satisfaction in altruistic, other-centered behavior" is a theme that is frequently expressed by persons with criminal histories (LeBel \& Maruna, 2012). Mutual aid is also a cornerstone for many alcohol- and drug-recovery 12-step programs, such as Alcoholics Anonymous and Narcotics Anonymous (Zemore, Kaskutas, \& Ammon, 2004). Therefore, it is not surprising that many of the individuals in our sample talked about wanting to help others who were struggling to escape lives of drugs and crime.

Dorothy, a 49-year-old African-American woman, works at a methadone clinic. Maria, a 52-year-old Latina, is currently unemployed, but volunteers at a center that provides housing, education, counseling, and advocacy for youth and families. Melissa's decade-long career in caregiving flowed out of her dedication to regain custody of her son. Unfortunately, due to their criminal records, some respondents’ aspirations for caregiving careers were limited or prohibited. Wanda noted, “I wanted to go to school to be a nurse. I couldn’t do that.” After

\footnotetext{
${ }^{7}$ A 'wet reckless' is a plea-bargained charge of violating California Vehicle Code $\$ 23103$ (misdemeanor reckless driving) pursuant to §23103.5. If the settlement is accepted, the prosecutor must note that alcohol or drug consumption was a factor (Caiafa \& Farnsworth, 1982).
} 
passing her exams, Melissa’s Certified Nurse’s Assistant license was revoked due to her criminal conviction. Sharon, a 56-year-old woman awaiting record clearance, noted: "I finally figured out what I love doing, and I love caregiving but I cannot really move ahead with the convictions on my record.”

Women in our sample also desired to obtain jobs where they could use their experiences to motivate others. They felt uniquely positioned to provide services to individuals who were homeless, addicted to drugs, and in trouble with the law. Having battled with these situations themselves, respondents believed they could empathize with others going through these struggles, be respected as credible, and provide advice from lived experiences that might help others recover or successfully reintegrate. Maria exemplified this when she said:

You know, I can't change what I've done in the past; I can't change any of that. And I think that's why I wanted to be like a social worker or a childhood advocate so because I couldn't help my own kids at least I could try to help someone else's, you know. Or make an impact in somebody else's life. Positive impact. Not a negative impact.

For Maria, becoming a social worker could be seen as making amends for her past, helping children since she was unable to help her own, and serving in a role, caregiving, that is consistent with gender expectations and norms.

Wanda has had a life filled with abuse and recovery. Sexually assaulted at an early age by an uncle and then later by other personnel during her eight-month service for the Army National Guard, Wanda started using drugs at age 22 and became homeless in her 20s. Now, clean and sober for ten years, Wanda currently works in a shelter and aspires to start a homeless shelter to provide desperately needed services to an underserved population to which she once belonged.

So there are four of us that are trying to start a shelter. Right now, I work in a shelter. Next Monday will be my last day because it's seasonal... and like the shelters now, they don't offer any type of skills or, you know, how to do a resume or how to dress for success. They get you there, you check in at six and you leave 
at six in the morning... we want to do something that is different. We want to have a year-round shelter where we can have mentors come in. We can have medical, dental, dieticians. We want to do something positive that's really going to transition someone to be self-sufficient because they aren't getting that now.

Having experienced similar difficulties as the population she serves, Wanda is uniquely positioned to know what services homeless individuals need, beyond what is typically provided. Her commitment to serve stems from her need she once had for services. O'Brien (2001) attests that giving back is a strategy women use to obtain citizenship in their community, a central factor in successful reintegration.

\section{Moral and religious motivations to change}

A far greater proportion of women (ten, or 55.6\%) than men (six, or 27.3\%) talked about moral or religious motivations to leave behind a life of drug abuse or crime and try to start over with a clean slate, or a relationship with God as a source of the strength they needed to desist and pursue a new path $\left(p=0.069, \chi^{2}=3.30,1\right.$ d.f. $)$.

For women who had a relationship with God, religion was instrumental in various stages preceding and throughout the record clearance process. Some received strength to quit their addiction, others to begin the process of record clearance, and yet others believed God had helped them accomplish their goal of record clearance. On the day Michelle, a 39-year-old, Caucasian and Native American mother of four, got her conviction cleared, she said she was “sweating but I was praying the whole time. I was like, 'Lord, I’m here cause you brought me through all those obstacles and today is going to be a victory day for me.’” This victorious moment she attributed to God.

Sharon, a 56-year-old, Caucasian/Native American woman who was convicted of multiple drug offenses, probation violation, and traffic offenses, noted that strengthening her 
Christian identity increased her desires to be law abiding: "My walk as a Christian has improved my self-control level... as a Christian I want to follow the laws, I want to do the right things.”

A newly formed/renewed relationship with God led other women to feel they had received a moral cleansing. Their subsequent interest in record clearance flowed out of a desire for their external life to match their internal feeling. Tina, an African-American woman in her late thirties, who was convicted of embezzlement after stealing from her employer in order to keep her daughter and herself out of a shelter, explained:

I think spiritually like when ... I found God it's more of like you know, he wipes our slate clean. And I feel like that's what he did for me. And ... I wanted it to look the same for my background as well.

Before, during, and after record clearance, women felt supported through their relationship with God. They credited him for helping them through life’s obstacles, enhancing their desire to follow the law and giving them a second chance at life. In this sense, God played an important role in some women's path towards and through record clearance.

\section{Concern about reputation}

Concern over one's reputation or what others thought was discussed as a reason to desist from drugs or crime by more than twice as many women (14, or $77.8 \%$ ) than men (seven, or 31.8\%) $\left(\mathrm{p}=0.004, \chi^{2}=8.386,1\right.$ d.f.). This is consistent with prior research. Dodge and Pogrebin (2001) found that once community members learned of formerly convicted women’s criminal history, their interaction with them and their children changed. The stigma of the criminal record followed the women after conviction, and the perception others, including their family members, held of them impacted their perception of themselves (Harm \& Phillips, 2001).

Sandra hoped that getting her record cleared would make her less subject to stigma and the feelings of shame and being misunderstood that resulted from others' negative perceptions: 
... [having a criminal record has] taken a toll definitely on my morale and the fact that okay it's kind of embarrassing because it's like I don't — the assumptions and like the stereotypical—well I mean that's natural. The assumptions that someone would have if I told them okay, "Yeah I have four DUIs and I was a drug addict and I drank." Obviously it's not going to paint a pretty picture. You know automatically there are going to be certain things that pop in someone's head about my character or my lifestyle. That may not necessarily be true.

Likewise, Angela spoke of how the stigma associated with her criminal record prevented her from even applying for jobs: “I wouldn’t even put myself out there. Because I felt shame if I would've gotten questioned about it because of the nature of the charges and it's the drugs and guns and how do you explain that?” The desire to alleviate her feelings of shame, and to have her record reflect the changed person that she had become, served as the impetus for initiating the record clearance process:

What finalized my decision was that I felt like I always carried around my rap sheet on my forehead. And I didn't want to live like that anymore. I knew I was a different person, I knew that what I had done I had paid for.

For these women, the criminal label had become a central part of their reputation. Their desire to reshape their reputation to match their new self-identity motivated them to seek record clearance.

\section{Breaking from the past}

Record clearance is expressly intended to help individuals with criminal convictions in their efforts to break from the past and access opportunities that have been denied due to their criminal records. Eighty percent of our interviewees talked about wanting to make a break from their past or actually doing so. All but one of the women in the sample (94.4\%) mentioned this desire, in contrast with 15 of 22 men (68.2\%) $\left(p=0.039, \chi^{2}=4.268,1\right.$ d.f.).

Many respondents spoke about breaking from the past by recalling a pivotal moment when the decision to do so was made with an especially strong sense of resolve. For example, Wanda, a 55-year-old African-American woman whose past is characterized by extensive 
physical and sexual victimization as well as 20 years of crack cocaine use, recalled an epiphany that occurred while she was incarcerated:

In 2004, I got sentenced to a year. All the other times, I went in for like a week, then 20 days. But then reality set in when I was sentenced to a year. I just thought, “God, I can’t keep living my life like this.” You know, it’s the emotional rollercoaster. I had no kind of security... So, when I went to jail, I just said, "I can't do this no more. I don't want to do drugs when I get out anymore.” And that was in 2004 and February of 2014, I've been clean and sober for ten years.

Being sentenced to a year forced Wanda to face the severity of her actions and recognize her "feared self." The experience set in motion her resolve to change, which led her to pursue record clearance.

Allison, a middle-aged Caucasian woman whose convictions, all related to substance abuse, damaged her relationships with her family and her employment prospects, described the commitment required to fully break from the past, using an analogy that closely echoed the concept of "knifing off” one’s past (Maruna, 2001). "It’s not a quick fix, it should be like... this is the final surgery that's done, you know, not a Band-Aid.”

In contrast, some men in our sample seemed unwilling to acknowledge a flawed identity or a need to break from the past. For example, Gene, a 32-year-old, single, unemployed, homeless white man with an $11^{\text {th }}$ grade education, described how he had taken items from a store and gotten convicted of petty theft, expressing surprise that he had been prosecuted. In his interview, he commented, “I know stealing’s wrong so I know better than that.” He also insisted, “petty theft is not like me,” and “I don’t do bad things, I don’t steal things - apparently I do, but...” Even after mentioning that he had also jumped bail, Gene remained reluctant to characterize any of his actions as criminal behavior. Marcus is a 36-year-old, unemployed (despite having had his record expunged), married African-American man with a college degree whose convictions were for marijuana and cocaine possession. He never acknowledged being a 
drug user or criminal, and instead attributed his problems to racism in the criminal justice system. While racism may indeed have been present, Marcus’s unwillingness to accept any responsibility for his situation seems to reflect a weak commitment to break from the past and change course, even after completion of record clearance.

\section{Developing a "replacement self"}

Persons with criminal convictions at times internalize negative images of themselves (Dodge \& Pogrebin, 2001). Developing a "replacement self” can be viewed as an avenue to overcome that perception. The idea of developing a "replacement self” was mentioned by 11 $(61.1 \%)$ of the women, in comparison to only seven $(31.8 \%)$ of the men $\left(p=0.064, \chi^{2}=3.432,1\right.$ d.f.). The first step towards the development of a "replacement self" for many of our interviewees was acknowledging that their former "self” was flawed and needed replacing. Julie, a 51-year-old single white woman, discussed how being sent to prison brought her to this realization:

...my whole thing was - because I'd never been to prison, I was normal. Because bad people go to prison. So, moving forward, my last arrest sent me to prison. So prison is where I was really willing to take a look at my life and to realize that I definitely had a problem.

Coming face to face with what Paternoster and Bushway (2009) would call her "feared self” - no longer "normal” and one of the "bad people" - provided momentum for Julie to change. ${ }^{8}$

Sandra, a 39-year-old, well-educated, first-generation Asian-American woman, whose drug and alcohol addiction led to four DUI convictions in her 20s but who is now married and

\footnotetext{
${ }^{8}$ Julie is a self-described "habitual offender" with numerous misdemeanor drug and prostitution convictions in Washington, Oregon, and California, along with a felony drug conviction that resulted in a prison sentence. Her last conviction was seven to nine years before she initiated record clearance. While she could not expunge all of her convictions (in her own words, "that prison thing is still there"), she was able to create a new identity and has demonstrated a commitment to maintaining stable relationships, sobriety, and legal employment as a bus driver.
} 
pregnant and starting a new career, compares her "replacement self” to a phoenix: "I feel like I’ve risen up from the ashes that I created.”

As part of the record clearance process, applicants are required to submit a petition detailing the legal and discretionary reasons for expungement. Here applicants have an opportunity to detail how they changed their lives subsequent to their conviction(s). They may discuss their work history, educational attainment, community service, abstinence, etc. Thus, the petition provides applicants with a prime opportunity to formulate and articulate a "replacement self.” The fact that more women in our sample mentioned this theme could be attributed to a higher level of introspection and self-criticism.

\section{Discussion}

\section{Motherhood and caregiving}

Our findings indicate that the desire to be a good caregiver to one’s children or other family members provides a strong incentive for many women to initiate record clearance and other positive changes. Many studies have found that individuals who make a commitment to caring for children have more successful desistance outcomes than those who assume no such responsibilities (see, e.g. LeBel \& Maruna, 2012; Maruna \& LeBel, 2002; Sampson \& Laub, 1993), though some scholars have questioned the extent to which this relationship is causal (Giordano, et al., 2002; Leverentz, 2014). Motherhood itself may facilitate desistance, because it leads to a greater sense of responsibility, more attention to the needs of others, and a better understanding of the consequences of one’s own behavior (McIvor, Murray, \& Jamieson, 2004). The desire to regain custody of their children and to serve as providers and role models for them is a powerful motivator for many women (Cobbina, 2010; Leverentz, 2014; O’Brien, 2001a; Opsal, 2011). This aligns with findings that “children can have a positive effect on women and 
can facilitate the development of a prosocial self-image” (Cobbina \& Bender, 2012, p. 282).

Many of the women in our sample perceived record clearance as an extension of their

commitment to developing a more normative, law-abiding life and positive identity-building, and part of a path to a better future for themselves and their children.

In addition to caring for their children, women with a criminal record, especially AfricanAmerican women, are often expected to care for other family members, such as spouses, parents, and siblings, and even more widely in their communities. The role of women as "community caregivers” has grown especially important in underprivileged neighborhoods, which have been destabilized as a substantial proportion of men have been removed through mass incarceration (Richie, 2002). This stands in contrast to the expectations of men with a criminal record, who often anticipate receiving support from family members upon their release (Leverentz, 2014). Leverentz (2014, p. 178) found that “women’s roles as mothers and as caregivers within their families were central to their identities, and sources of shame and guilt when they fell short in either role, during their addictions and during their attempts at desistance.” The fact that so many women experience external and internal expectations to provide support for their children and other family and community members places additional pressure on them to obtain well-paying jobs and stable residences (Cobbina \& Bender, 2012). Record clearance may be a step towards doing so.

\section{Caregiving as a vocation}

If record clearance can help clients gain access to jobs in child care, elder care, medical assistance, and drug treatment, it may be particularly valuable for women with criminal records, given the propensity of many women to pursue "helping professions," the known benefits of 
engaging in "helper" activities, and the power of work as a "hook for change" for women undergoing cognitive transformation (Opsal, 2012).

In contrast to most other professional identities, for which a criminal background is inconsistent or even disqualifying, "wounded healer” or "professional ex-" roles allow FCPs to take ownership of, and draw from, their criminal histories as sources of knowledge, wisdom, empathy, and credibility as role models, helpers, or mentors for individuals with similar backgrounds who are seeking to desist from drugs and crime (Cressey, 1965; Maruna, 2001). Reconceptualization of one's past in this manner can help FCPs reconcile their former and current/future identities (Aresti et al., 2010). Although there is limited empirical research on whether mutual aid between FCPs is beneficial for the recipients of this type of assistance, some studies have provided theoretical arguments, as well as empirical support, for the idea that serving as a "professional ex-" provides numerous benefits to those who serve as "helpers" (Cressey, 1965; Maruna, 2001; Riessman, 1965). These benefits include development of positive social relationships, a sense of purpose, facilitation of moral development, feelings of empowerment, improvements in self-esteem, greater satisfaction with life, a reduction in criminal attitudes, a stronger commitment to desistance, development of job experience and leadership skills, and a way to spend time engaged in productive pursuits rather than in deviant activities (Aresti et al., 2010; Cressey, 1965; LeBel, 2007; LeBel et al., 2015; Maruna \& LeBel, 2002; Riessman, 1965). Another, indirect, effect is the reduction of stigma that can result from increased interaction between those in the stigmatized group and others in society (LeBel, 2008) - an outcome that may eventually arise when more FCPs can have their records expunged and become more engaged in professional, residential, and social contexts. 
To the extent that institutional programs can be designed to recognize FCPs' strengths, reward positive achievements, and encourage stigmatized individuals to "make good," e.g. by working in professions where they care for others, they can facilitate identity transformation and successful reintegration of FCPs (Maruna and LeBel, 2003). Criminal record expungement, when carried out through a formal court hearing, represents a powerful "de-labeling” process, which can remove some of the stigma attached to an individual's past and provide encouragement and support to those who are ready to move forward as productive community members (Adams et al., 2017; Maruna, 2001). It also allows people with criminal records to make amends in the form of contributions to society (Bazemore \& Erbe, 2004; LeBel, Richie, \& Maruna, 2015; O’Brien, 2001a).

The men in our sample, while often engaged in caregiving, did not speak about caregiving in the same way that women did. Their roles as fathers, rehabilitation specialists, medical employees, and caseworkers for gang-involved youth were discussed in relation to the work they did rather than the care they gave. The social organization of work differentiates masculine and feminine attitudes and behaviors, with caregiving relegated to women (Connell, 1987; West \& Zimmerman, 1987). In not speaking about their caregiving roles, the men in our sample were both "doing gender" - behaving consistently with societal expectations of men and resisting gender roles - by not characterizing their work as engaging in caring, a role traditionally reserved for women (Connell, 1987; West \& Zimmerman, 1987). Since women are socialized to be more responsive to others' needs (Steffensmeier \& Allan, 1996), it is understandable that the women in our sample were more articulate about the care they provided. Furthermore, in articulating their desire to provide care, women were vocalizing alignment with gender norms while negotiating reentry into a gendered society. 


\section{Moral and religious motivations}

Several women in our sample expressed gratitude to God for helping to facilitate their desistance, and expressed a desire to reciprocate by leading a lawful and morally righteous lifestyle. The propensity to credit a higher power, rather than free will, for important life changes may reflect many women's lack of feelings of agency and control over certain aspects of their lives; however, religious faith may provide the extra strength and confidence that enables some women to complete record clearance and to sustain their progress during reentry.

There are numerous potential theoretical linkages between religiosity or spirituality and motivation or success in the reintegration process. Religious guidelines may also help people define the behaviors to engage in, and to avoid, as they craft a replacement identity after some or all of their criminal past has been "erased” through record clearance. Organized religion can provide an accessible “cognitive blueprint” for prosocial decision making and behavior for individuals who may lack appropriate role models and examples in their social environments (Giordano, et al., 2008). Identification as a religious person may increase one’s social capital and respectability; religious teachings may offer a mechanism of external social control; a spiritual or religious community can serve as a prosocial network; and feelings of being forgiven and loved by God may provide emotional support and feelings of peace and happiness that reduce the stress that might otherwise manifest itself in violent behavior or drug abuse (Bakken, Gunter, \& Visher, 2013; Giordano, Longmore, Schroeder, \& Seffrin, 2008). Women may also have stronger desires to build and maintain spiritual relationships, just as they care more about personal relationships. Herrschaft, et al. (2009) found that a greater proportion of women than men discussed God or another spiritual being as a factor in their personal narratives of transformation during reentry. Furthermore, the nature of men’s and women’s language about God differed: a 
man “portrayed God as an external factor” that enabled a miraculous turnaround, in contrast to a woman who spoke of an "intimate relationship” with God, which “provided support for her decision to change” (Herrschaft et al., 2009).

Our findings support the idea that women may be more motivated than men to adopt prosocial identities and lifestyles in order to improve their social bonds to others (Herrschaft et al., 2009). This may manifest itself not only in interpersonal relationships, but also in a stronger inclination to abide by societal moral and ethical norms. A study that incorporated interviews with 275 Scottish youth found a number of differences between young men and young women in their desistance behavior: "[f]emale respondents were... more likely than their male counterparts to cite moral as opposed to utilitarian rationales for stopping offending and were more likely to emphasize the importance of relational aspects of this process” (McIvor et al., 2004, p. 194).

While our analysis does not permit us to draw conclusions about the effects of religion or spirituality on the ability to sustain long-term desistance from drugs or crime, the findings do indicate that women’s narratives are more likely than men’s to include testimonials regarding how religious faith contributed to the wherewithal and discipline they needed to complete the steps necessary to have their records cleared and to rebuild their lives as clean and sober, crimefree members of society.

\section{Concern about reputation}

The stigma attached to a criminal record - even if it entails only a single minor offense can have pervasive effects on nearly all aspects of a FCP’s life (Jacobs, 2015). With increased accessibility of criminal records, this stigma becomes more and more difficult to avoid (Jacobs, 2015). Drug use and criminal offending among women may attract greater social stigma than it does among men, as it violates not only the law, but also gender norms (LeBel, 2008; Maruna, 
2001; McIvor et al., 2004). The effects of stigmatization include experiences of rejection by others; psychological consequences of anticipated rejection, which can prevent FCPs from placing themselves in situations where they are likely to experience stigma, such as applying for jobs, volunteer opportunities, or housing; fear of discovery among individuals who are trying to conceal their criminal past; and withdrawal from social interactions, the workforce, or other situations by those who experience this fear (Adams, et al., 2017; LeBel, 2008). These forces exacerbate the isolation and disadvantage experienced by individuals with criminal records.

Since actions are undertaken with consideration of how others will view them (West \& Zimmerman, 1987), it is understandable that women become more concerned with their reputation as they attempt to reenter law-abiding society. They no longer want to be associated with criminal labels, and they want their actions to reshape their reputation. Women with criminal convictions may also be more concerned about social standing and reputation than their male counterparts because of the centrality of relationships to women's self-perceptions (Herrschaft et al., 2009). Indeed, in a study that entailed interviews with nine men and nine women with criminal records in Northern Ireland, Byrne and Trew (2008, p. 249-250) found that women more often spoke about pressure to "conform to conventional social values" and expressed concerns about "other people’s negative reactions to their involvement in crime.” Campbell (1987) found that Puerto Rican girls involved in gangs were exceedingly concerned about their "self presentation" and that motherhood, caregiving, monogamy, and maintaining a good reputation were central to young women's positive identities (Campbell, 1987).

Although women may suffer more stigmatization initially when convicted of a crime, society may maintain "greater hope that female offenders can be reformed” (Maruna, 2001, p. 176). Thus, while women's reputations may be more susceptible to damage as a result of a 
criminal record, they may also be more amenable to repair through "socially responsible activities” like education and work (Uggen \& Kruttschnitt, 1998, p. 362). As a result, women may be more motivated than men to desist from drug use and crime and to erase the negative marks on their records and gain access to such activities through record clearance, and they may be better-rewarded when they do so.

\section{Breaking from the past and developing a "replacement self"}

In their accounts of the decision-making processes that preceded the pursuit of record clearance, many of our study participants described experiences that reflected stages of identity transformation identified in prominent theoretical frameworks on desistance and reentry. These included (1) recognition and acknowledgement of flaws in their criminal or drug-using identity; (2) awareness of a "feared self"; (3) a resolution to "break from the past" to avoid this "feared self”; and (4) development of a "replacement self” (Giordano, et al., 2002; Paternoster \& Bushway, 2009). Many of our interviewees spoke of reaching the first three stages before initiating record clearance. For those who completed it, record clearance was especially valuable at the fourth stage. It enabled individuals to shed some of the stigma they had accumulated and repair a tarnished reputation, and provided a path to move forward with a new identity.

Record clearance, and in particular the act of completing the petition, may be especially helpful to women as it helps them articulate flaws in their former identities and the criminal activities they engaged in, identify successful steps they have taken to distance themselves from their former identities and behaviors, and conceptualize the new identities they are embracing. The ability to complete the process left several individuals with feelings of accomplishment and control over their future. 
However, when it came to the realities of actually breaking from the past and creating a replacement self, women spoke less about voluntary changes in their living environment and associates; rather, these changes, when they occurred, tended to be described in terms of luck, the benevolence of others, or acts of God. In other words, women tended to attribute the ability to make these changes to forces outside their own control. Furthermore, relationships played a central role in both women's decisions to undertake identity change and their frequent inability to do so. Decisions to desist from crime and drugs were often made with the needs or opinions of others in mind, but ties to family and friends sometimes hindered processes of change.

These findings suggest that primarily-individualistic models of identity change and desistance - such as the identity model of change (Paternoster \& Bushway, 2009; Rocque, et al., 2016) - may accurately describe the thought processes of many FCPs, but contextual and societal circumstances - including those associated with gender expectations - play an especially important role in women's experiences as they attempt to carry out the steps needed to break from the past and build new lives as law-abiding and productive members of a gendered society (Giordano, et al., 2008; Giordano, et al., 2007).

\section{Conclusion and Policy Implications}

An increasing number of women and men with criminal convictions are living in our communities. Policymakers face the challenge of reintegrating them into society. Record clearance offers one way for people with criminal records to demonstrate a commitment to desistance and formally remove some of the stigma associated with their past. Individuals who are able to have convictions removed from their records can gain greater access to jobs and opportunities to participate in legitimate activities; as a result, they have more alternatives to crime. Record clearance facilitates the process of turning away from a criminal identity and 
behaviors and moving forward with a positive identity and prosocial lifestyle. The findings from this study add nuance to the existing scholarly work on desistance and reintegration, highlighting ways in which women's motivations and efforts to reinvent themselves as law-abiding members of society (e.g. through record clearance) differ from men’s experiences.

The individuals in our sample were not representative of all FCPs; rather, they were a self-selected group who had expressed an interest in, or completed, the expungement process. Successful completion of voluntary programs like job training and record clearance, and especially removal of offenses from one’s record, can serve as a useful, albeit imperfect, signal of likely desistance, which can help employers, housing providers, and others sort out low-risk FCPs from those who are more likely to recidivate (Bushway \& Apel, 2012). Consequently, the completion of record clearance can facilitate reentry and reintegration by opening doors to jobs and homes. In the case of record clearance, the judge who presides over the court hearing and ultimately determines whether to grant an expungement further validates a FCP's motivation and ability to desist. The hearing itself can have a powerful effect, transforming the FCP's relationship with the criminal justice system from one characterized by distrust and antagonism to one that includes mutual respect and feelings of legitimacy (Adams et al., 2017). Maruna and LeBel (2002), writing about strengths-based models for reentry courts, discuss the value of opportunities for "earned redemption" recognized in public "elevation ceremonies" that formally restore and certify FCPs' status as law-abiding members of society. Record clearance hearings serve this function.

The heterogeneity among the participants in our study in socioeconomic status and education raises questions regarding whether the experiences and efficacy of record clearance vary for individuals with different levels of social capital. Giordano, et al. (2002) explain that 
individuals with high levels of social capital usually do not need to experience cognitive transformation to desist, while those with the least social capital are unlikely to benefit much from it. Our data analysis did not provide sufficient empirical evidence to draw conclusions regarding whether this point extends to record clearance. The participants in our study who described successful outcomes included people whose past and/or current socioeconomic status was highly disadvantaged, as well as those from working- and middle-class (or higher) environments. Record clearance enabled a range of clients to obtain employment, although prior education and job experience did, of course, affect the types of jobs they were able to secure. Some of the interviewees stated that they would not have been able to complete record clearance, and enjoy its benefits, if the program had not been free of charge.

The process of completing a petition and hearing for record clearance requires the construction of a narrative that acknowledges the applicant's flawed past and explains how he or she has changed. The women in our sample seemed more willing than the men to engage in selfcritical reflection and to admit flaws with their former selves, rather than trying to justify or downplay bad decisions, blaming others, making excuses, or trying to reframe their addictions or criminal histories as not entirely negative, as individuals engaged in "rebiographing” have been found to do (Maruna, 2001). This makes them more willing to discard their flawed identities and seek to replace them, traits that make them amenable to cognitive transformation and successful completion of the record clearance process. Many women viewed record clearance as a vital step in this identity transformation process, providing a chance to start with a clean slate.

Many of the women in our study were motivated to pursue record clearance by intrinsic motivations - e.g. a desire to live a moral life and become a good person. When they cited extrinstic motivations for change, these reasons tended to be oriented towards relationships, e.g. 
serving others as parents, caregivers, or volunteers, or concern about social standing and reputation. This finding is consistent with Herrschaft, et al.’s work (2009), which found that relationships were especially important motivators for women to desist from drugs and crime. In addition to providing support and encouragement, our female interviewees' ties to others often generated feelings of obligation and guilt that compelled the women to abandon drugs and crime, seek a fresh start through record clearance, and rebuild their identities as contributors to their families, peer groups, and communities.

Our findings indicate that women’s narratives describing reasons for pursuing record clearance contain a greater emphasis on caring for others both as a motivation to desist and as a personal or professional goal once a new identity has been formed. Many women spoke about working to help others as educators, medical assistants, counselors, or advocates, currently or in the future. A number of studies have identified serving in a "helper" role as a valuable part of the criminal rehabilitation process (Cressey, 1965; LeBel, 2007; LeBel et al., 2015; Riessman, 1965). Our findings suggest that these roles may be particularly well-aligned with the proclivities of female FCPs.

Record clearance was viewed by many respondents, especially women, as a first step towards being able to serve in a professional caregiving role, for example by gaining permission to volunteer or work in schools, or obtaining certifications or licenses to work in health care professions (our sample included individuals who sought careers as nurse’s assistants, home health aides, and phlebotomists). Caregiving is a central component of many traditionally female-dominated professions where demand for workers is high and growing, such as nursing and geriatric care (U.S. Department of Labor, 2014). Unfortunately, these jobs usually require background checks and licenses that are unattainable for people with criminal records (Jacobs, 
2015). Record clearance can help women access stable employment opportunities that align well with their interests and inclinations.

Women also spoke more often than men about how they were motivated to desist and pursue a prosocial new identity by concern about their reputation. This reflects the relative importance of social bonds for women. It may also be a result of the dual stigma associated with having a criminal record and violating social expectations with regard to femininity and womanhood (including motherhood) (Byrne \& Trew, 2008; McIvor et al., 2004). However, because women are often considered less blameworthy for their criminal behavior and more amenable to rehabilitation (Maruna, 2001; Spohn \& Beichner, 2000), the stigma of being an FCP may be more easily attenuated by women who take advantage of record clearance.

\section{Policy implications}

Record clearance is beneficial for both men and women, but it may be particularly compatible with women's motivations, willingness to change, and personal and professional goals. Women with criminal convictions are more likely to have drug or nonviolent convictions and usually serve shorter sentences. Therefore, they may be more likely to be eligible for record clearance, and they may face fewer of the obstacles that are associated with long-term incarceration. Our analysis finds that they are more interested in creating a replacement self, are more interested in careers in caregiving, are more likely to have moral and religious motivations to change, and are generally more concerned with their reputation. These differences must be considered to create successful programs for both women and men.

Pre-release and reentry programs should engage women in discussions about their past, current, and future reputation and self-image, their desire to create a replacement self, and strategies for building a new prosocial identity. Through these conversations, programmers can 
assess signals to determine whether women are ready and committed to changing their lives (Bushway \& Apel, 2012), and direct eligible clients who are ready to embrace a new self-identity toward opportunities like record clearance.

Persons with lower-level convictions who are most likely to qualify for record expungement may eventually have opportunities to pursue (or reestablish) careers in caregiving. Our research indicates that this option might be particularly attractive to women. The prospect of record clearance, and subsequent opportunities for training and licensing as caregivers, could be a powerful incentive for certain FCPs to desist from drugs and crime. Working in helping professions could also help FCPs maintain their desistance, while earning income to provide for themselves and their dependents. Therefore, expanding expungement opportunities and lifting some prohibitions for lower-level FCPs to obtain access to professional caregiving roles could be beneficial in many ways. Alternatively, policy changes to prevent certain less-serious offenses from becoming part of criminal records in the first place - such as pre-sentencing diversion programs - could help ensure that access to certain opportunities remains available to those who are unlikely to pose a danger to others, while circumventing the processes of sentencing, punishment, reentry, and expungement.

Religious faith can be a source of motivation to pursue record clearance as well as a source of strength and guidance to commit to a law-abiding lifestyle after record clearance. Although reentry programs that include religious elements are not appropriate for all clients, recent empirical research supports the idea that some individuals may be particularly responsive to faith-based correctional programs (Bakken et al., 2013; Dodson, Cabage, \& Klenowski, 2011; Giordano et al., 2008; Johnson, 2004). More research is needed to determine the efficacy of reentry programs with religious or spiritual components. If such programs have positive effects, 
they may be especially effective for women who consider their relationship with God very important.

Through our interviews, we learned that many of our participants initially were not aware that there was a possibility to have their records cleared when they were released from jail. During the exit procedure that inmates complete before they are released from custody, they should be informed about whether any of their offenses are eligible for expungement/felony reduction, the benefits of expungement, and requirements for record clearance. This information should also be provided in a brief pamphlet with a list of resources for record clearance. If FCPs are informed about the prospect of eligibility for record clearance early after their conviction, this might also serve as an incentive to seek rehabilitation opportunities and to desist. Distribution of information about programs such as the Record Clearance Project in women's correctional facilities can be especially helpful since these programs address needs and goals that emerge often with women with criminal records.

While participating in the record clearance does not necessarily lead to desistance, the ability to successfully complete such a program can indicate to other members of society that an individual is prepared to leave drugs and crime behind. It also provides formal affirmation of an individual's new identity, which can introduce legitimacy and mutual respect into the FCP's relationship with criminal justice authorities (Maruna \& LeBel 2002; Adams, et al., 2017). Increasing the availability of record clearance can help more reformed persons with criminal records distance themselves from the past and establish prosocial identities - essential components of the transformation process that women seem more motivated than men to undertake - while helping to control public safety risks and improve FCPs' ability to contribute to society by facilitating more successful reintegration. 


\section{References}

Adams, E., Chen, E. Y., \& Chapman, R. (2016). Erasing the Mark of a Criminal Past: ExOffenders' Expectations and Experiences with Record Clearance. Punishment \& Society, 19(1), p. 23-52.

Andrews, D. A., \& Dowden, C. (2007). The risk-need-responsivity model of assessment and human service in prevention and corrections: Crime-prevention jurisprudence. Canadian Journal of Criminology and Criminal Justice 49(4), 439-464.

Arditti, J. A., \& Few, A. L. (2006). Mothers' reentry into family life following incarceration. Criminal Justice Policy Review, 17(1), 103-123.

Aresti, A., Eatough, V., \& Brooks-Gordon, B. (2010). Doing time after time: an Interpretative Phenomenological Analysis of reformed ex-prisoners' experiences of self-change, identity and career opportunities. Psychology, Crime \& Law, 16(3), 169-190.

Bakken, N. W., Gunter, W. D., \& Visher, C. A. (2013). Spirituality and desistance from substance use among reentering offenders. International Journal of Offender Therapy and Comparative Criminology 58(11), 1321-1339.

Bates, R. E. (2004). Women prisoners and recidivism: Factors associated with re-arrest one year post-release. Children, Families, and the Criminal Justice System, Spring.

Bazemore, G., \& Erbe, C. (2004). Reintegration and restorative justice: Towards a theory and practice of informal social control and support. After crime and punishment: Pathways to offender reintegration, 27-56.

Benda, B. B. (2005). Gender differences in life-course theory of recidivism: A survival analysis. International Journal of Offender Therapy and Comparative Criminology, 49(3), 325342.

Benda, B. B., Harm, N. J., \& Tooms, N. J. (2005). Survival analysis of recidivism of male and female boot camp graduates using life-course theory. Journal of Offender Rehabilitation, 40(3-4), 87-113.

Blitz, C. L. (2006). Predictors of stable employment among female inmates in New Jersey: Implications for successful reintegration. Journal of Offender Rehabilitation, 43(1), 1-22.

Bloom, B., Owen, B., \& Covington, S. (2004). Women Offenders and the Gendered Effects of Public Policy. Review of policy research, 21(1), 31-48.

Bui, H. N., \& Morash, M. (2010). The impact of network relationships, prison experiences, and internal transformation on women's success after prison release. Journal of Offender Rehabilitation, 49(1), 1-22.

Brown, G. (2010). The intersectionality of race, gender, and reentry: Challenges for AfricanAmerican women. American Constitution Society for Law and Policy, Issue Brief.

Bushway, S. D., \& Apel, R. (2012). A signaling perspective on employment-based reentry programming. Criminology \& Public Policy, 11(1), 21-50.

Bureau of Justice Statistics (2015) Survey of State Criminal History Information Systems, 2014. U.S. Department of Justice, Office of Justice Programs.

Byrne, C. F., \& Trew, K. J. (2008). Pathways through crime: The development of crime and desistance in the accounts of men and women offenders. The Howard Journal of Criminal Justice, 47(3), 238-258.

Caiafa, D., \& Farnsworth, A. R. (1982). Under the Influence of California's New Drunk Driving Law: Is the Drunk Driver's Presumption of Innocence on the Rocks. Pepperdine Law Review, 10, 91-138. 
Charmaz, K. (2006). Constructing grounded theory: A practical guide through qualitative analysis. Thousand Oaks, CA: Sage Publications, Inc.

Charmaz, K. (2011). Ground theory methods in social justice research. In. N. K. Denzin \& Y. S. Lincoln (Eds.), The SAGE handbook of qualitative research. (pp. 359-380). Thousand Oaks, CA: Sage Publications, Inc.

Cobbina, J. E. (2010). Reintegration success and failure: Factors impacting reintegration among incarcerated and formerly incarcerated women. Journal of Offender Rehabilitation, 49(3), 210-232.

Cobbina, J. E., \& Bender, K. A. (2012). Predicting the future: Incarcerated women’s views of reentry success. Journal of Offender Rehabilitation, 51(5), 275-294.

Connell, R.W. (1987) Gender and Power. Stanford: Stanford University Press.

Cressey, D. R. (1965). Social Psychological Foundations for Using Criminals in the Rehabilitation of Criminals. Journal of research in crime and delinquency, 2(2), 49-59.

Curcio, G., Pattavina, A. and Fisher, W. (2016). Gender differences on the road to redemption, Feminist Criminology. http://journals.sagepub.com/doi/full/10.1177/1557085116654566.

Desmond, M. (2012). Disposable Ties and the Urban Poor. American Journal of Sociology, 117(5), 1295-1335.

Dodson, K. D., Cabage, L. N., \& Klenowski, P. M. (2011). An Evidence-Based Assessment of Faith-Based Programs: Do Faith-Based Programs "Work” to Reduce Recidivism? Journal of Offender Rehabilitation, 50(6), 367-383.

Mihoko Doyle, J., \& Kao, G. (2007). Are racial identities of multiracials stable? Changing selfidentification among single and multiple race individuals. Social psychology quarterly, 70(4), 405-423.

Ehrensaft, M., Khashu, A., Ross, T. \& Wamsley, M. (2003). "Patterns of criminal conviction and incarceration among mothers of children in foster care in New York City.” New York, NY: Vera Institute of Justice.

Giordano, P. C., Cernkovich, S. A., \& Rudolph, J. L. (2002). Gender, Crime, and Desistance: Toward a Theory of Cognitive Transformation. American Journal of Sociology, 107(4), 990-1064.

Giordano, P. C., Longmore, M. A., Schroeder, R. D., \& Seffrin, P. M. (2008). A Life-Course Perspective on Spirituality and Desistance from Crime. Criminology, 46(1), 99-132.

Giordano, P. C., Schroeder, R. D., \& Cernkovich, S. A. (2007). Emotions and Crime over the Life Course: A Neo-Meadian Perspective on Criminal Continuity and Change. American Journal of Sociology, 112(6), 1603-1661.

Herrschaft, B. A., Veysey, B. M., Tubman-Carbone, H. R., \& Christian, J. (2009). Gender differences in the transformation narrative: Implications for revised reentry strategies for female offenders. Journal of Offender Rehabilitation, 48(6), 463-482.

Huebner, B. M., DeJong, C., \& Cobbina, J. (2010). Women coming home: Long-term patterns of recidivism. Justice Quarterly, 27(2), 225-254. DOI: 10.1080/07418820902870486

Jacobs, J. B. (2015). The Eternal Criminal Record. Cambridge, MA: Harvard University Press.

Johnson, B. R. (2004). Religious programs and recidivism among former inmates in prison fellowship programs: A long-term follow-up study. Justice Quarterly, 21(2), 329-354.

Kirk, D. S. (2012). Residential Change as a Turning Point in the Life Course of Crime: Desistance or Temporary Cessation? Criminology, 50(2), 329-358.

Lalonde, R. J., \& Cho, R. M. (2008). The impact of incarceration in state prison on the employment prospects of women. Journal of Quantitative Criminology, 24(3), 243-265. 
Laub, J. H., \& Sampson, R. J. (2003). Shared beginnings, divergent lives: Delinquent boys to age 70. Cambridge, MA: Harvard University Press.

LeBel, T. P. (2007). An examination of the impact of formerly incarcerated persons helping others. Journal of Offender Rehabilitation, 46(1-2), 1-24.

LeBel, T. P. (2008). Perceptions of and Responses to Stigma. Sociology Compass 2(2): 409-432.

LeBel, T. P., \& Maruna, S. (2012). Life on the Outside: Transitioning from Prison to the Community. The Oxford Handbook On Sentencing and Corrections. New York, NY: Oxford.

LeBel, T. P., Richie, M., \& Maruna, S. (2015). Helping Others as a Response to Reconcile a Criminal Past The Role of the Wounded Healer in Prisoner Reentry Programs. Criminal Justice and Behavior, 42(1), 108-120.

Leverentz, A. (2010). People, places, and things: How female ex-prisoners negotiate their neighborhood context. Journal of Contemporary Ethnography, 39(6), 646-681. DOI: 10.1177/0891241610377787.

Leverentz, A. M. (2014). The Ex-prisoner's Dilemma: How Women Negotiate Competing Narratives of Reentry and Desistance: New Brunswick, NJ: Rutgers University Press.

Maruna, S. (2001). Making good: How ex-convicts reform and rebuild their lives: American Psychological Association.

Maruna, S., \& LeBel, T. P. (2002). Revisiting ex-prisoner re-entry: A buzzword in search of a narrative. Reform and punishment, 158-180.

Maruna, S., \& LeBel, T. P. (2002). Welcome Home-Examining the Reentry Court Concept from a Strengths-Based Perspective. Western Criminology Review 4, 91-107.

Mauer, M. (2013). The changing racial dynamics of women's incarceration: Sentencing Project.

McIvor, G., Murray, C., \& Jamieson, J. (2004). Desistance from crime: Is it different for women and girls. After crime and punishment: Pathways to offender reintegration, 181-197.

Mears, D. P., \& Cochran, J. C. (2014). Prisoner Reentry in the Era of Mass Incarceration: Thousand Oaks, CA: Sage Publications.

Messerschmidt, J. W. (2009). "Doing gender”: The impact and future of a salient sociological concept. Gender and Society, 23(1), 85-88.

Michalsen, V. (2011). "Mothering as a life course transition: Do women go straight for their children?” Journal of Offender Rehabilitation, 50, 349-366.

Miller, J. (2002) The strengths and limits of 'doing gender' for understanding street crime. Theoretical Criminology, 6(4), 433-460.

O’Brien, P. (2001a). “Just like baking a cake”: Women describe the necessary ingredients for successful reentry after incarceration. Families in Society: The Journal of Contemporary Social Services, 82(3), 287-295.

O’Brien, P. (2001b). Making it in the free world: Women in transition from prison: SUNY Press.

Opsal, T. (2011). Women disrupting a marginalized identity: Subverting the parolee identity through narrative. Journal of Contemporary Ethnography 40(2), 145-167.

Opsal, T. (2012). 'Livin’on the Straights': Identity, Desistance, and Work among Women PostIncarceration. Sociological Inquiry, 82(3), 378-403.

Opsal, T. (2015). “It’s Their World, so You’ve Just Got to Get Through” Women’s Experiences of Parole Governance. Feminist Criminology, 10(2), 188-207.

Owen, B. (2009). Accounts of change and resistance among women prisoners. How offenders transform their lives, (eds. B. Veysey, J. Christian, and D. Martinez), 104-123. 
Paternoster, R., Bachman, R., Bushway, S., Kerrison, E., \& O’Connell, D. (2015). Human agency and explanations of criminal desistance: Arguments for a rational choice theory. Journal of Developmental and Life-Course Criminology, 1(3), 209-235.

Paternoster, R., \& Bushway, S. (2009). Desistance and the "feared self": Toward an identity theory of criminal desistance. The Journal of Criminal Law and Criminology, 1103-1156.

Petersilia, J. (2003). When prisoners come home: Parole and prisoner reentry. Oxford, UK: Oxford University Press.

Richie, B. E. (2001). Challenges incarcerated women face as they return to their communities: Findings from life history interviews. Crime \& Delinquency, 47(3), 368-389.

Richie, B. E. (2002). The social impact of mass incarceration on women. Invisible punishment: The collateral consequences of mass imprisonment, (eds. M. Mauer, \& M. ChesneyLind),136-149.

Riessman, F. (1965). The” helper” therapy principle. Social work, 27-32.

Rocque, M., Posick, C., \& Paternoster, R. (2016). Identities through time: an exploration of identity change as a cause of desistance. Justice Quarterly, 33(1), 45-72.

Sampson, R. J., \& Laub, J. H. (1993). Crime in the making: Pathways and turning points through life. Cambridge, MA: Harvard University Press.

Saperstein, A., \& Penner, A. M. (2010). The race of a criminal record: How incarceration colors racial perceptions. Social Problems, 57(1), 92-113.

Sentencing Project (2015). “Fact Sheet: Incarcerated Women and Girls.” Retrieved from http://www.sentencingproject.org/wp-content/uploads/2016/02/Incarcerated-Women-andGirls.pdf.

Spohn, C., \& Beichner, D. (2000). Is preferential treatment of female offenders a thing of the past? A multisite study of gender, race, and imprisonment. Criminal Justice Policy Review, 11(2), 149-184.

Steffensmeier, D., \& Allan, E. (1996). Gender and crime: Toward a gendered theory of female offending. Annual Review of Sociology, 22, 459-487.

Thomas, D. R. (2006). A general inductive approach for analyzing qualitative evaluation data. American Journal of Evaluation, 27(2), 237-246.

Uggen, C., \& Kruttschnitt, C. (1998). Crime in the breaking: Gender differences in desistance. Law and Society Review, 339-366.

U.S. Department of Labor, Bureau of Labor Statistics (2014). Table 1.4 Occupations with the most job growth, 2014 and projected 2024. Retrieved from http://www.bls.gov/emp/ep_table_104.htm.

West, C., \& Zimmerman, D. H. (1987). Doing gender. Gender \& Society, 1(2), 125-151.

Wright, E. M., Van Voorhis, P., Salisbury, E. J., \& Bauman, A. (2012). Gender-Responsive Lessons Learned and Policy Implications for Women in Prison: A Review. Criminal Justice and Behavior, 39(12), 1612-1632.

Zemore, S. E., Kaskutas, L. A., \& Ammon, L. N. (2004). In 12-step groups, helping helps the helper. Addiction, 99(8), 1015-1023. 